\title{
Intensive Care Unit Nursing Competence Assessing Awareness With GCS (Glasgow Coma Scale) Techniques
}

\author{
$1^{\text {st }}$ Rudi Kurniawan \\ Nursing Study Program \\ STIKes Muhammadiyah Ciamis \\ Jl. K.H. Ahmad Dahlan, Ciamis, \\ Indonesia \\ akhrud28@gmail.com \\ $4^{\text {th }}$ Irpan A.R \\ Nursing Study Program \\ STIKes Muhammadiyah Ciamis \\ Jl. K.H. Ahmad Dahlan, Ciamis, \\ Indonesia
}

\author{
$2^{\text {nd }}$ Suhanda \\ Nursing Study Program \\ STIKes Muhammadiyah Ciamis \\ Jl. K.H. Ahmad Dahlan, Ciamis, \\ Indonesia \\ $5^{\text {th }}$ Adi Nurapandi \\ Nursing Study Program \\ STIKes Muhammadiyah Ciamis \\ Jl. K.H. Ahmad Dahlan, Ciamis, \\ Indonesia
}

\author{
$3^{\text {rd }}$ Endrian M.J.W \\ Nursing Study Program \\ STIKes Muhammadiyah Ciamis \\ Jl. K.H. Ahmad Dahlan, Ciamis, \\ Indonesia \\ $6^{\text {th }}$ Elis Noviati \\ Nursing Study Program \\ STIKes Muhammadiyah Ciamis \\ Jl. K.H. Ahmad Dahlan, Ciamis, \\ Indonesia
}

\begin{abstract}
The Glasgow coma scale (GCS) is an instrument used by paramedics to measure the decrease in patient awareness. GCS instruments are often used in emergency rooms, intensive care units (ICU), and neurological units. Impairment of consciousness is a dangerous condition for the patient's life rate and is an indicator of patient death. The purpose of this study was to analyze the competence of ICU nurses to measure the decrease in patient awareness. The research method used was a cross-sectional study which involved 43 ICU nurses, 10 questions about competency to evaluate knowledge and competence. The results showed that years of service had a significant effect on nurses' competencies in assessing neurology with a p-value of 0.007. Conclusion Assessment of patient awareness is needed so that the competency of nurses needs to be maintained consistency by refreshing new knowledge.
\end{abstract} Scale)

Keywords-Intensive Care, Nursing, GCS (Glasgow Coma

\section{INTRODUCTION}

The Incentive Care Unit is an inpatient for patients who have critical characteristics. Critical patients in intensive care units consist of patients suffering from chronic pain, complications, and trauma. This study requested that trauma patients after getting observation in the Emergency Department will then be transferred to the ICU for further treatment or even surgery. Regarding trauma management, examination, resuscitation, and appropriate treatment care are very important to determine the death rate of patients [1]. Because the examination is very important to do examinations in patients with trauma using GCS [2]. GCS was developed by Taesdale and Jennet in 1974 which consisted of eye examinations having a score of 1 to 4 , verbally having a score of 1 to 6 and motorics having a score of 1 to 5 [3]. In this study, we want to see the characteristics of nurses consisting of age, education and years of service. Other research shows the length of school study, length of work and experience in the intensive care unit will affect nurses' GCS knowledge. This study discusses the relationship between age, education and years of service on the competence of ICU nurses.

\section{METHODS}

This study uses analytic surveys to determine the relationship between two variables. Calculation of statistical analysis using Chi-Square. The study sample was all ICU nurses in 3 government public hospitals namely in Banjar City, Ciamis Regency, and Tasikmalaya City with a total of 43 respondents. Measurement of nurses' ability was measured using a questionnaire consisting of 3 questions regarding the characteristics of respondents, 5 questions regarding GCS theory, 5 questions about scenarios, or not the active period of the training. The questionnaire was tested for validity and reliability at Garut Hospital with a sample of 20 people. All questionnaires were tested and the results were valid. The sample has nurses' inclusion criteria who have emergency department training certificates and served in the ICU. Exclusion criteria were nurses who served structurally (head of the room and deputy head of the room) and were on leave/permission/ sick / not on duty. Samples were taken based on total sampling and crosssectional.

\section{RESULTS}

TABLE 1. NURSE CHARACTERISTICS WITH GCS COMPETENCY RESULTS FOR INTENSIVE CARE UNIT (ICU) DEPARTMENT NURSES

\begin{tabular}{|l|c|c|c|c|c|c|c|}
\hline \multirow{4}{*}{ Characteristic } & \multicolumn{6}{|c|}{ Results of competencies in ICU department } \\
& \multicolumn{2}{|c|}{$\begin{array}{c}\text { Good } \\
\text { competence }\end{array}$} & \multicolumn{2}{c|}{$\begin{array}{c}\text { less } \\
\text { competence }\end{array}$} & \multicolumn{2}{|c|}{ Total } & $\begin{array}{c}\text { P } \\
\text { Value }\end{array}$ \\
\cline { 2 - 8 } & $\mathrm{F}$ & $\%$ & $\mathrm{~F}$ & $\%$ & $\mathrm{~F}$ & $\%$ & \\
\hline Age & 20 & 46 & 23 & 54 & 43 & 100 & 0,280 \\
\hline
\end{tabular}




\begin{tabular}{|l|c|c|c|c|c|c|c|}
\hline $\begin{array}{l}\text { level of } \\
\text { education }\end{array}$ & 19 & 44 & 24 & 56 & 43 & 100 & 0,397 \\
\hline $\begin{array}{l}\text { length of } \\
\text { working }\end{array}$ & 20 & 46 & 23 & 54 & 43 & 100 & 0,007 \\
\hline
\end{tabular}

Table 1 shows that the length of work has a close relationship with the competence of ICU nurses in evaluating awareness using GCS. The p-value of 0.007 indicates that there is a relationship, while education and length of work do not have a relationship with nurse competence.

\section{DISCUSSION}

The paramedics have good knowledge but not necessarily with competence so that in some cases there are still many errors found in assessing GCS so that training needs to be forced to minimize the error of GCS assessment [4]. Seeing the fact that this study shows that age and education do not have a significant effect. Even the length of work has a significant relationship. Thus in line with previous studies, the ability of GCS must be forced by age, medics can have good competence in GCS. Good GCS competence will certainly have a large benefit effect where the prediction of death will be better detected in patients with trauma in the ICU. In accordance with the development carried out in GCS to make it simple and can be used as easily as possible to prevent mortality in trauma patients [5] has a significant influence on nurses' competencies in using GCS because a simple model will cut the length of action and increase GCS accuracy so as to prevent things that are beyond predictions. There should be a structured standard regarding training and then an examination for nurses on GCS must be scheduled so that nurse competence is maintained [6]. So it is not only the days of work that only has an influence on the ability of nurses in conducting GCS but when nurses enter the ICU already have these competencies. GCS modification has been done mainly for use in trauma patients in order to maintain the accuracy and ease of nurses to use such as modifying GCS to assess GCS predictive head trauma plus pupillary reactions [7] then modifying GCS with a score of 13 for moderate head trauma [8] This shows that the accuracy of GCS must be maintained and adjusted to the ability of nurses as predictors in the ICU. In some countries, GCS is still considered complicated and difficult to apply [9] so that there need to be modifications that are adapted to language and perception to facilitate the use of GCS in terms of language and interpretation of perception. GCS is a measure of awareness so that there is in triage [10] therefore nurses also need to improve their ability in triage. Also, GCS measurements need to be standardized in the assessment of hospitalized patients as a standard of hospital care [11]. So that they can be applied easily without differences in perception.

\section{CONCLUSION}

The nurse's competence in assessing GCS in the ICU really needs attention. The need for trained nurses who can use good GCS instruments becomes the demand of nurses working in the ICU Room. For this reason, consistent, scheduled and structured training is the answer to correct these problems.

\section{REFERENCES}

[1] Y. Kondo, T. Abe, K. Kohshi, Y. Tokuda, E. F. Cook, and I Kukita, "Revised trauma scoring system to predict in-hospital mortality in the emergency department: Glasgow Coma Scale , Age , and Systolic Blood Pressure score," Crit. Care, vol. 15, no. 4, p. R191, 2011.

[2] J. B. Brown et al., "Evidence-based improvement of the National Trauma Triage Protocol: The Glasgow Coma Scale versus Glasgow Coma Scale motor subscale Joshua," vol. 77, no. 1, pp. 95-102, 2015.

[3] W. C. Santos et al., "Assessment of nurse' s knowledge about Glasgow coma scale at a university hospital em um hospital universitário," vol. 14, no. 55 11, pp. 213-218, 2016.

[4] C. Heim, P. Schoettker, N. Gilliard, and D. R. Spahn, "Knowledge of Glasgow coma scale by air-rescue physicians," BioMed Cent., vol. 6, pp. 1-6, 2009.

[5] M. Gerdin, N. Roy, M. Khajanchi, V. Kumar, L. Felländer-tsai, and M. Petzold, "Validation of a novel prediction model for early mortality in adult trauma patients in three public university hospitals in urban India," BMC Emerg. Med., pp. 1-12, 2016.

[6] G. Teasdale, A. Douglas, P. Brennan, E. McElhinney, and L. Mackinnon, "Forty years on : updating the Glasgow Coma Scale," Nurs. Times, vol. 110, no. 42, pp. 12-16, 2014.

[7] M. Majdan, M. Rusnak, and H. F. Lingsma, "Glasgow Coma Scale Motor Score and Pupillary Reaction To Predict Six-Month Mortality in Patients with Traumatic Brain Injury : Comparison of Field and Admission Assessment," vol. 108, pp. 101-108, 2015.

[8] A. B. Peitzman, J. L. Sperry, M. I. Gutierrez, and J. C. Puyana, "Effect of the Modified Glasgow Coma Scale Score Criteria for Mild Traumatic Brain Injury on Mortality Prediction: Comparing Classic and Modified Glasgow Coma Scale Score Model Scores of 13," vol. 71, no. 5, pp. 1185-1193, 2012.

[9] A. O. Adeleye, M. O. Owolabi, T. B. Rabiu, and A. E. Orimadegun, "Physicians, knowledge of the Glasgow Coma Scale in a Nigerian university hospital : is the simple GCS still too complex ?," vol. 3, no. March, pp. 1-7, 2012.

[10] W. Febrina, I. O. Sholehat, N. Programe, F. De Kock, and H. Science, "Experience of Nurse Assosiate To Implement Triage in," vol. 3, no. 1, pp. 138-145, 2018.

[11] A. Deharja and S. J. Swari, "Desain Formulir Assesment Awal Medis Gawat Darurat Berdasarkan Standar Akreditasi Rumah Sakit Versi 2012 di Rumah Sakit Daerah Balung Jember,” pp. 358-363, 2017. 